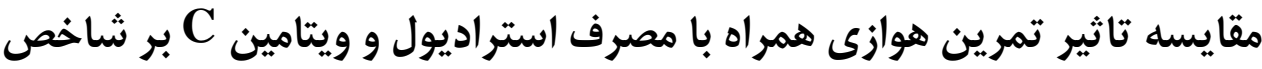 آسيب هاى كبد در رت هاى اور كتومى و نرمال
}

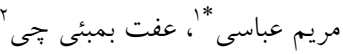

ا) كروه فيزيولوزى ورزشى، دانشكاه آزاد (سلاميc، ولحد ايلام، إيلام، ايرلن

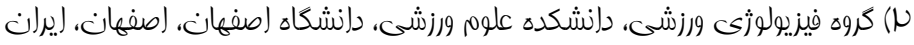

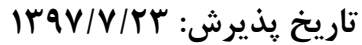

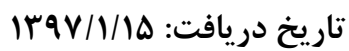

\section{جكيده}

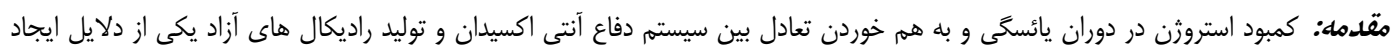

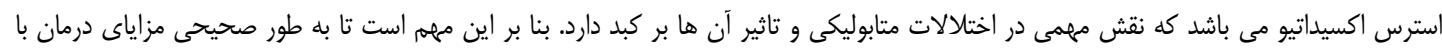

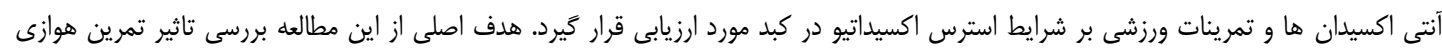

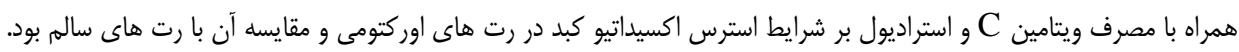

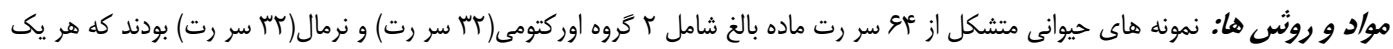

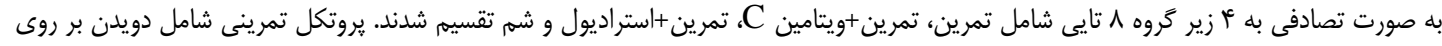

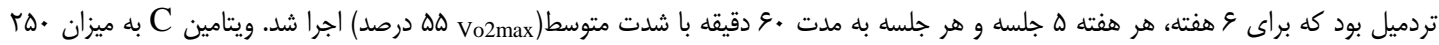

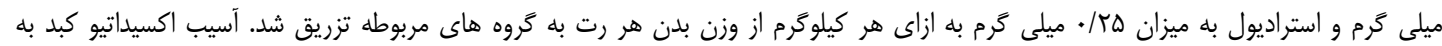

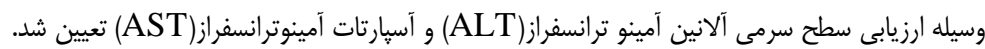

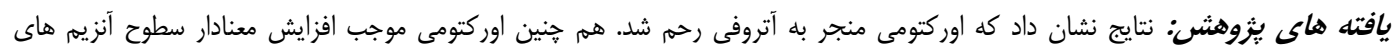

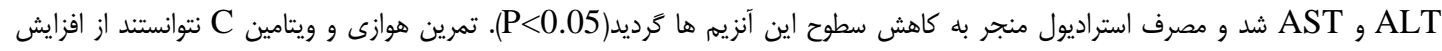

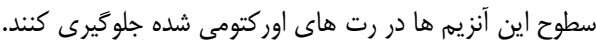

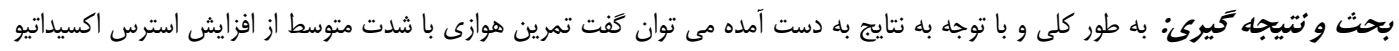

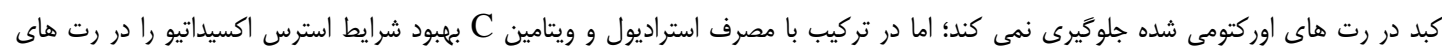
اوركتومى شده به دنبال دارد.

$$
\text { وازه هاى كليدى: استرس اكسيداتيو، يائسگى، تمرينات هوازى، ويتامين C، استراديول، اوركتومى }
$$


سينه، رحهم و تخمدان را در افراد مصرف كننده افزايش

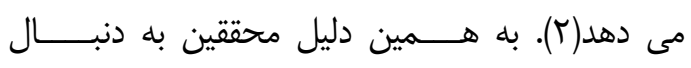

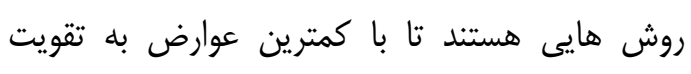
سيستم دفاع آنتى اكسيدانى در دوران يائسكى بيردازند

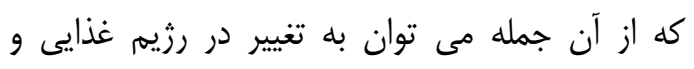

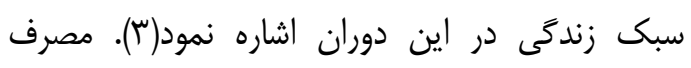

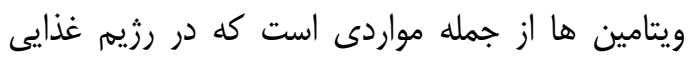

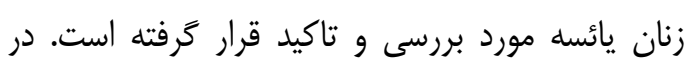

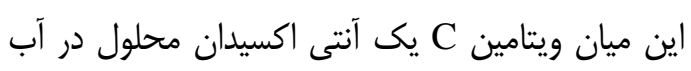

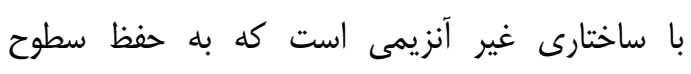

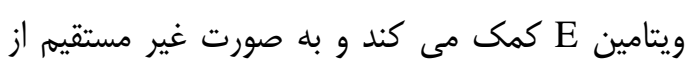

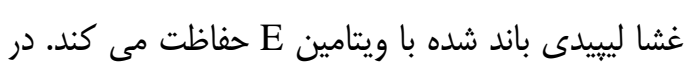

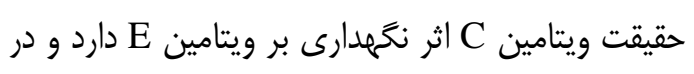

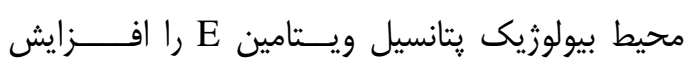

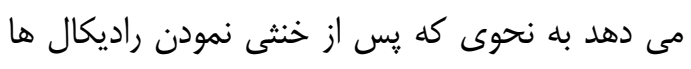

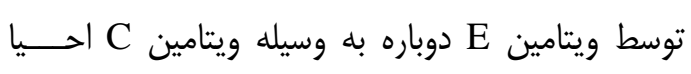
مى شود. بنا بر اين به نوعى ويتامين C اولين سيستم دفاعى عليه استرس اكسيداتيو مى باشد(أ). تغيير در سبك زندگى و داشتن فعاليت ورزشى نيز

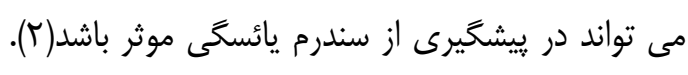
در رابطه با نقش ورزش در سيستم دفاع آنتى اكسيدانى

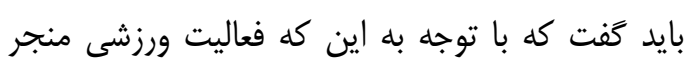
به افزايش حجم اكسيثن مصرفى، تغييرات در هموستاز

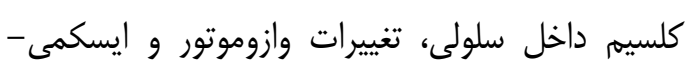

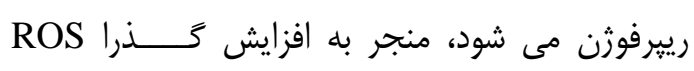

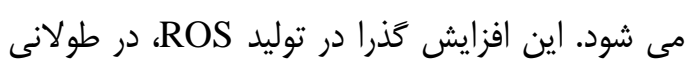

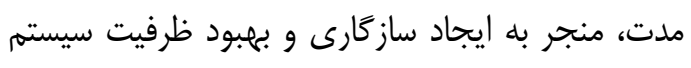

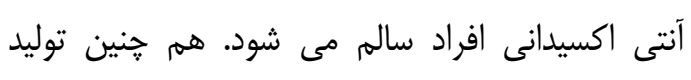
ROS

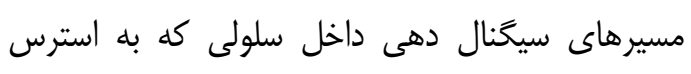
اكسيداتيو حساس هستند، مثل مسيرهاى بروتئين كيناز

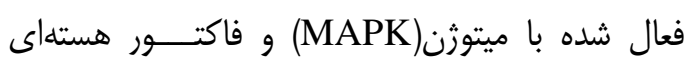
كاياى بتا(NF-K

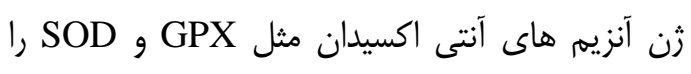

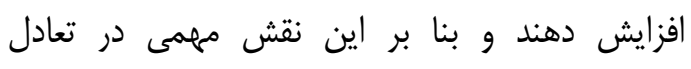

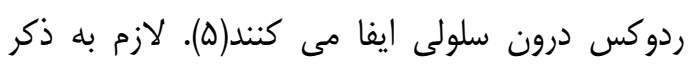
است كه در رابطه با تاثير فعاليت ورزشى بر در سيسته دفاع آنتى اكسيدانى در دوران يائسكى تحقيقات محدود ريطا
مقدمه توليد قابل توجه گَونه هاى فعال اكسيثن و

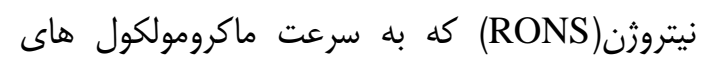

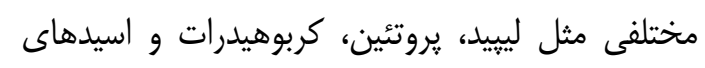

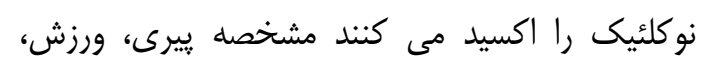

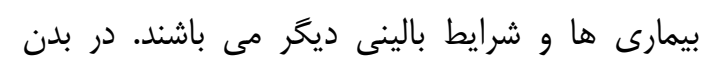

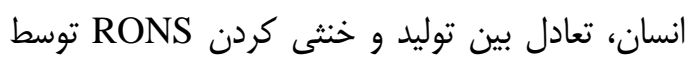
سيستم دفاع آنتى اكسيدان حفظ مى شود. اخر توليد فراتر از توانايى سيستم دفاع آنتى اكسيدان

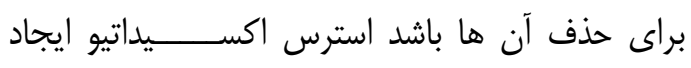

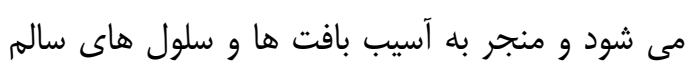

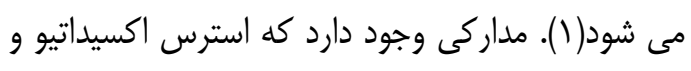
سيستم دفاع آنتى اكسيدان با جنسيت در ارتباط است.

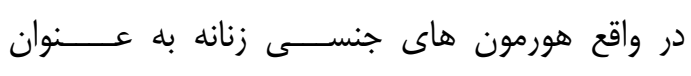
آنتى اكسيدان عمل مى كنند(؟).

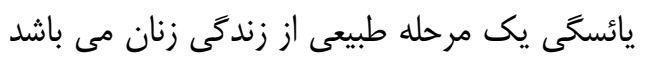

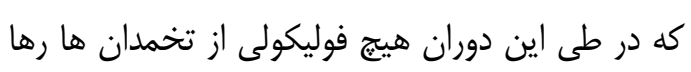
نمى شود و قاعدگى به علت كاهش ميزان استروزن

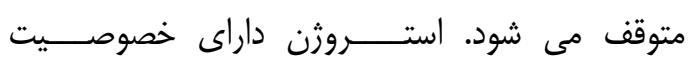
آنتى اكسيدانى مى باشد كه اين خصوصيت آن آن مربوط

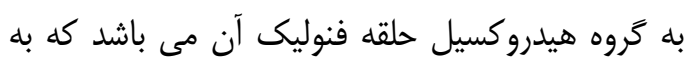
عنوان يك دهنده الكترون عمل مى كند، راديكال هاى

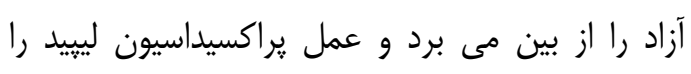

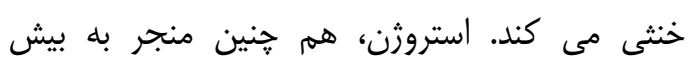
تنظيمى بيان خن آنزيم هاى آنتى اكسيدانى مثل سوير

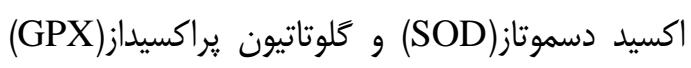
مى شود(Y). كمبود اين هورمون در دروان يائسكى

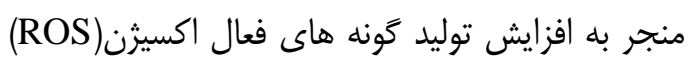

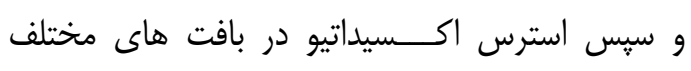
مى شود. اين مسئله در نهايت منجر به توسعل علائم و

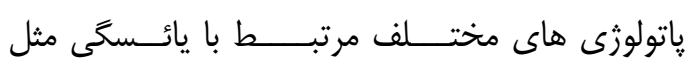
استئويروز، بيمارى قلبى -عروقى، ير فشار خونى، ديابت مرئ و آلزايمر مى شود(سّ).

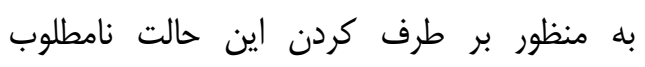
ردوكس ناشى از كمبود استروثن، تدابير خاصى مورد

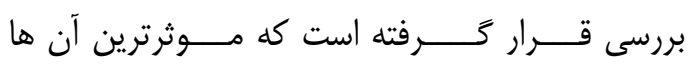
هورمون درمانى مى باشد؛ اما در عين حال ريسك بيمارى هاى كرونر قلبى، آمبوليسم ريوى و سرطان دران 
تاثير اختلالات متابوليكى ناشى از اوركتومى بر كبد از

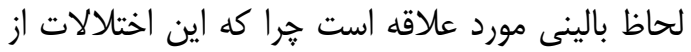
طريق توليد ROS ممكن اسـت منجر به تشديد بيمارى هاى كبدى مثل بيمارى كبد هرب غئ غير الكلى و سميت كبدى غير الكلى شود. نشت ALT و AST از غيماري

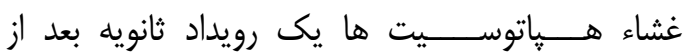

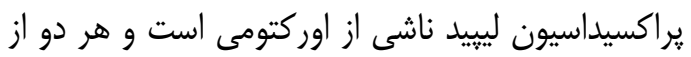

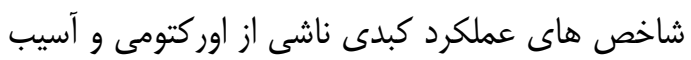
كبدى مى باشند(^). مطالعات نشان داده اند كه تمرينات ورزشى منظه منجر به كاهش توليد ROS در كبد و بهبود سلامت

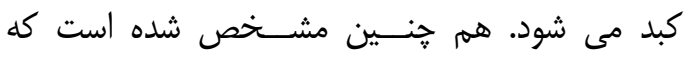
تمرينات ورزشى منظهم منجر به بيش تئ تنظيمى سيسته دفاع آنتى اكسيدان و كاهش تنظيمى توليد ROS در كبد مى شود(·(). بنا بر اين هدف از مطالعه حاضر مقايسه تاثير تمرين هوازى همراه با مصرف استراديول و ويتامين Cبر بيوماركرهاى استرس اكسيداتيو در كبد همراند

$$
\text { رت هاى اوركتومى و نرمال بود. }
$$

مواد و روش هات هات

تعداد عاع سر رت صحر ايى ماده سفيد از نزاد ويستار

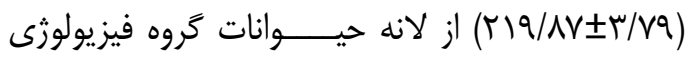
دانشخاه علوم يزشكى اصفهان(دانشكده يزشكى) تهيه شد. در طول مطالعه، رت ها تحت شرايط استاندارد و

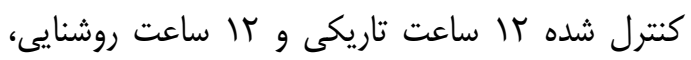

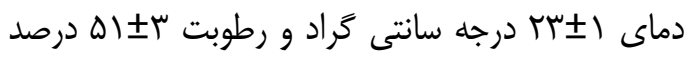
در قفس هاى مخصوص از جنس فايبر كالاس نكَهدارى

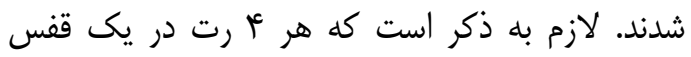
نكمهدارى شد. در طول كل دوره مطالعه روزانه آب و

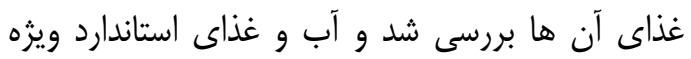
رت در اختيار آن ها قرار كرفت نمونه هاى حيوانى به صورت تصادفى به دو كروه

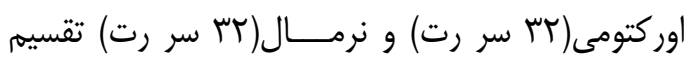

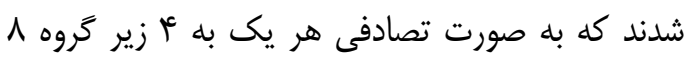

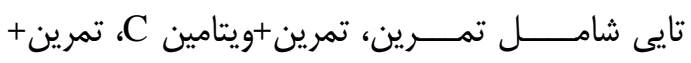
استراديول و شم كروه بندى شدند. در طول مطالعه تمبن

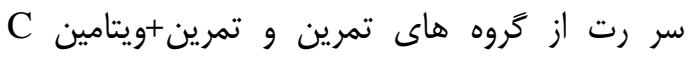
مربوط به كروه هاى نرمال از بين رفتند(شكل شماره

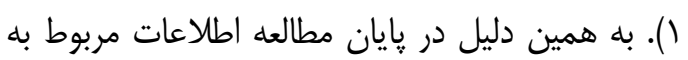

و ضد و نقيضى وجود دارد(F،V). در يك مطالعه مشخص شده است كه تمرينات شنا در طولانى مدت باعث بهبود سازكارى هاى آنتى اكسيدانى در رت هات هاى

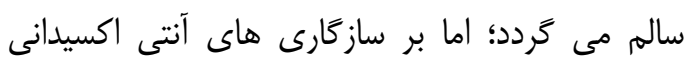

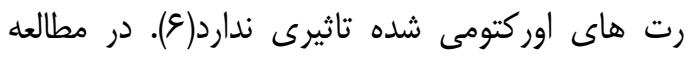
ديخر نيز رودريخس و همكاران(با +r)، نشان دادند كه تمرينات مقاومتى ميزان استرس اكسيداتيو كبد را در رت هاى اوركتومى شده افزايش مى دهد. اين محققين

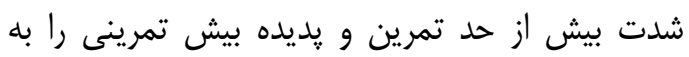
عنوان علت احتمالى افزايش استرس اكسيداتيو ذكر

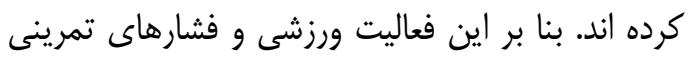
ناشى از آن از طرفى مى تواند موجب ساز كارى و بهببود

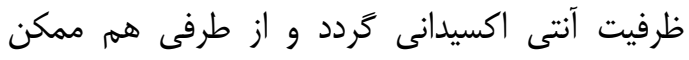

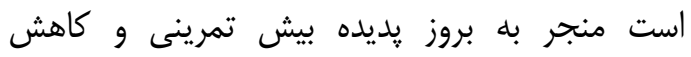

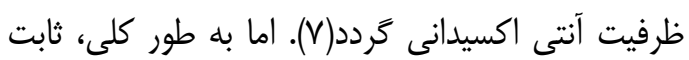

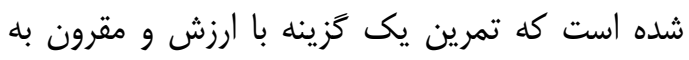

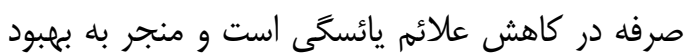
تعادل ردوكس در زنان يائسه سالم مى شود(؟ّ).

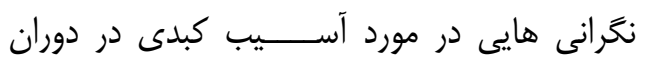

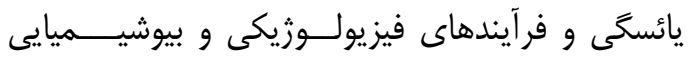
متعددى كه طى اين دوران مى تواند بر عملكرد كبد فيد فئس

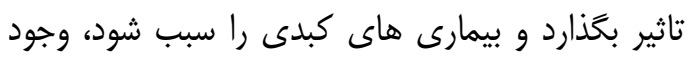

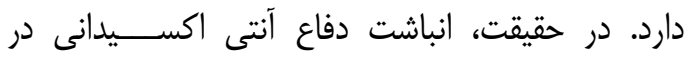

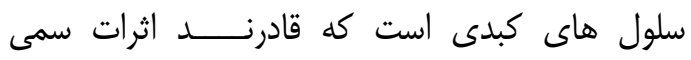

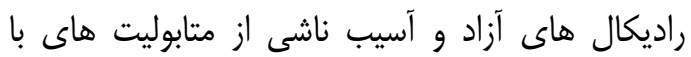
واكنش يذيرى بالا را بهبود بخشند. تغييرات ايجاد شده آنا در كبد ممكن است نشان دهنده شرايط اكسيدانت/

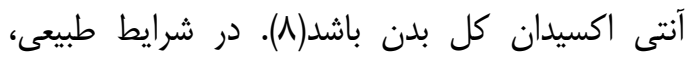

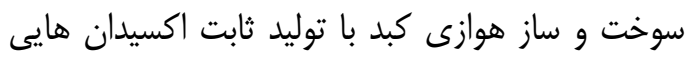
مانند ROS و مصرف آن ها با سرعت مشابه توسط

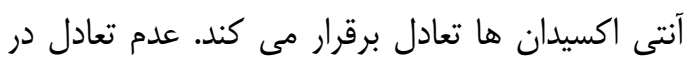

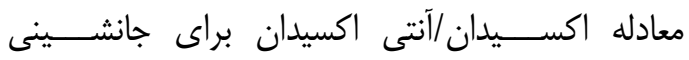
اكسيدان ها فرضيه استرس اكسيداتيو را در كبد مطرح

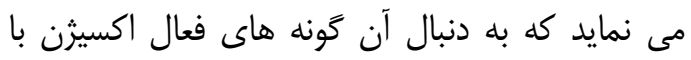
اثرات سمى خود منجر به يراكسيداسيون ليييد غشاء

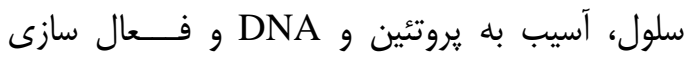
سلول هاى ماهواره اى مى شود. اين فرآيند منجر به فيه فيبروز، التهابات مزمن و آيويتوز در كبد مى شى شود(9). 


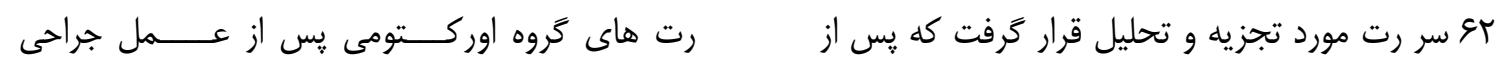

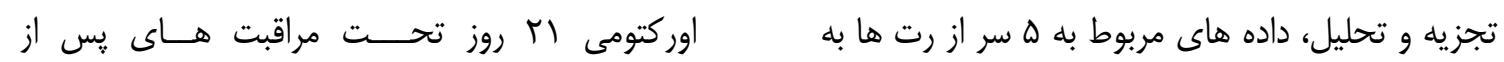

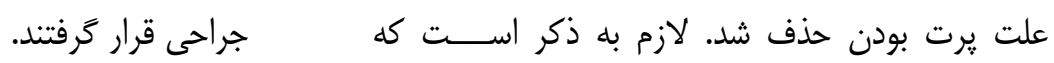

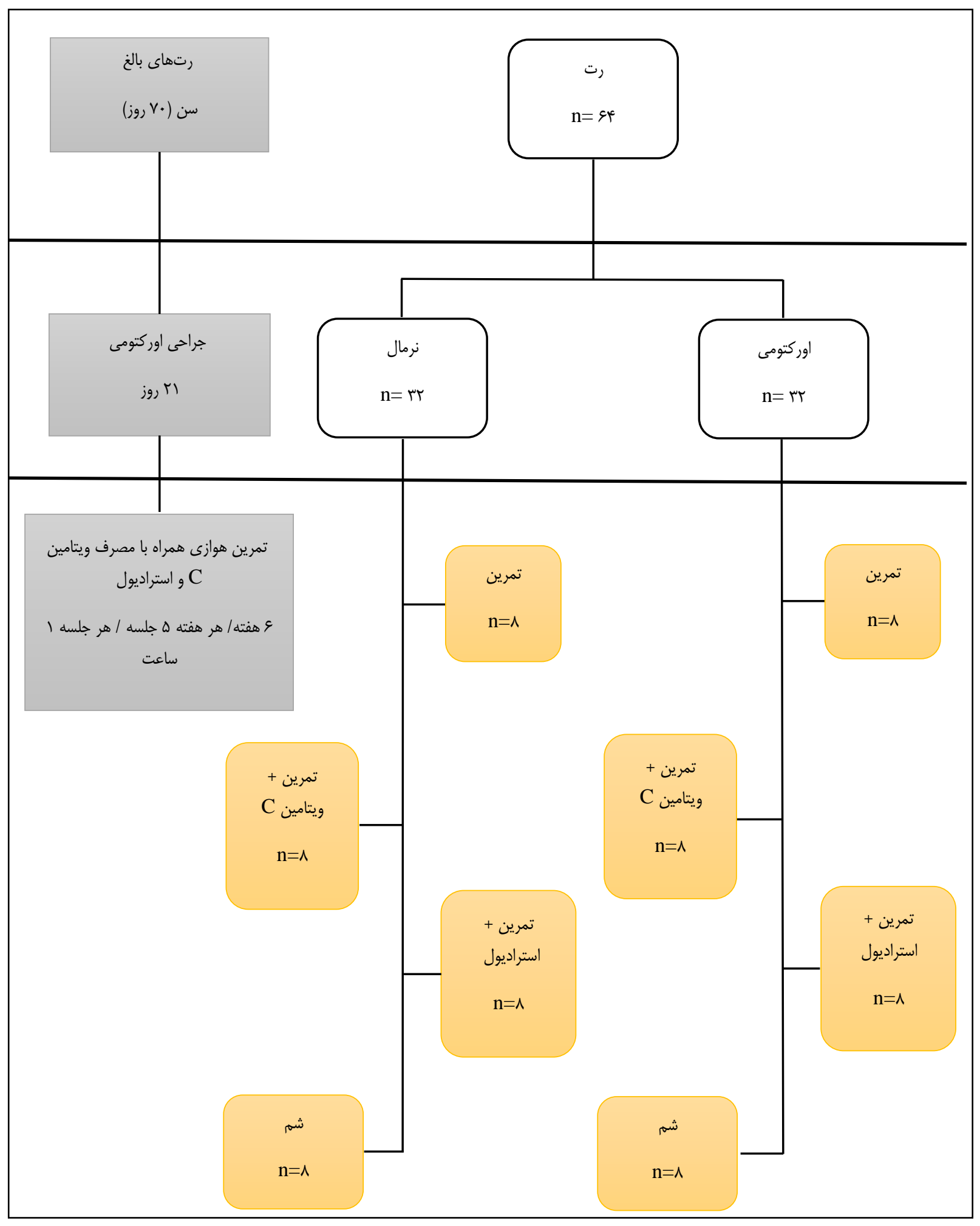

شكل شماره ا.طرح شماتيك تحقيق 
اساس وزن هر رت به كروه تمرين+استراديول تزريق شد. اين تزريق فقط در دو هفته اول يروتكل(هفته اي يك بار) و يس از اتمام تمرين دويدن بر روى تردميل

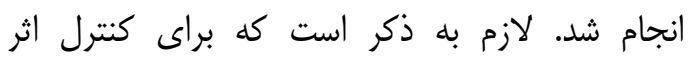
استرس ناشى از اين تزريق به كروه هاى ديخر فقط

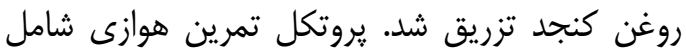

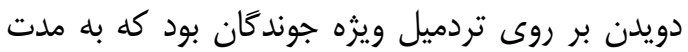

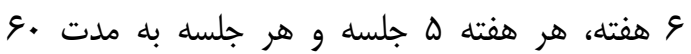
دقيقه اجرا شد (جدول شماره ()). لازم به ذكر است كه هـ جه يروتكل طراحى شده با شدت كم-متوسط|(ه درصد تا • ل.

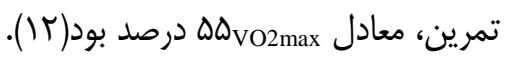

مكمل ويتامين C، طى يك دوره 9 هفته اى به

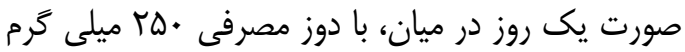

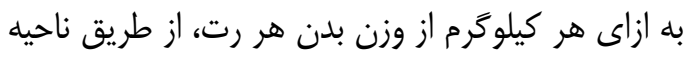

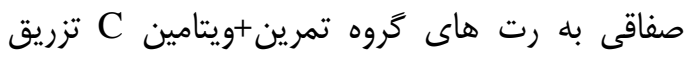
شد. لازم به ذكر است كه به منظور كنترل اثر استرس ناشى از تزريق، به ساير گروه ها نيز ماده بـى اثر سالين

به صورت صفاقى تزريق شد(1).

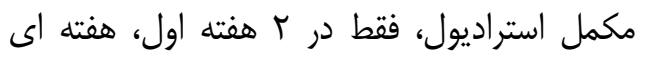

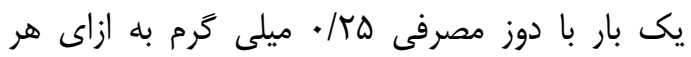
كيلوكرم از وزن بدن هر رت به صورت تزريق عضلانى به ناحيه عضلات جهار سر ران در قسمت بيرون انجام

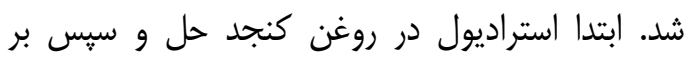

جدول شماره ا. بروتكل تمرين هوازى دويدن بر روى تردميل

\begin{tabular}{|c|c|c|c|}
\hline هفته هاى ينجمم و ششم & هفته هاى سوم و جهمارم & هفته هاى اول و دوم & متغيرهاى تمرين \\
\hline . 9 دقيقه & . 9 دقيقه & . & مدت تمرين \\
\hline • • متر بر دقيقه كيلومتر & ها ها متر بر دقيقه & • •ا متر بر دقيقه & مسافت بيمودوه شمرين \\
\hline
\end{tabular}

براى تجزيه و تحليل داده ها از نرم افزار آمارى SPSS ميانكين و انحراف معيار از آمار توصيفى و براى مقايسه سطوح متغيرها در گروه هاى مختلف از آزمون تحليل واريانس يك طرفه(ANOVA) استفاده شد. لازم بـ كريه ذكر است كه در صورت وجود تفاوت بين گروهيى از آزمون تعقيبى كمترين تفاوت معنى دار(LSD) استفاده شد. سطح معنادارى P

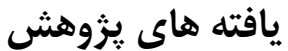

در رابطه با وزن رحم نتايج تحقيق نشان داد كه بين گروه هاى مختلف تحقيق اختالاف معنادارى در درد

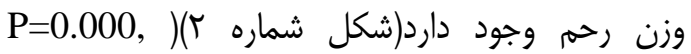
F=15.16). نتايج آزمون تعقيبى نشان داد كه وزن رحم دماردمار

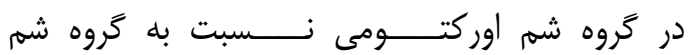

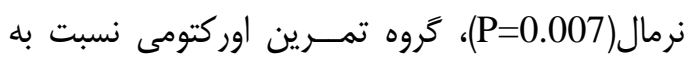
كروه تمرين نرمال(P=0.001) و كروه تمرين +ويتامين

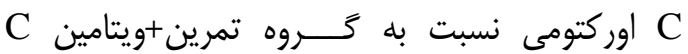
نرمال(P=0.000) به طور معنادارى كمتر بوده است. اما

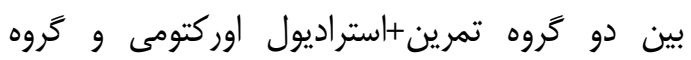
تمرين+استراديول نــــــــال تفاوت معنـادارى مشاهده

$$
\text { نشد(P=0.366). تمرين }
$$

مرحله نمونه بردارى بافتى و خون، يس از اتمام

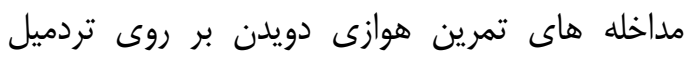
همراه با مصرف ويتامين C و استراديول انجام شد. ابتدا هر يك از رت ها وزن كشى شدند و به منظور كاهش

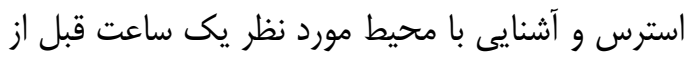

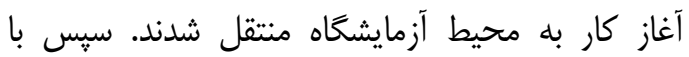

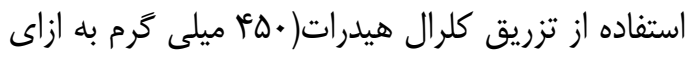

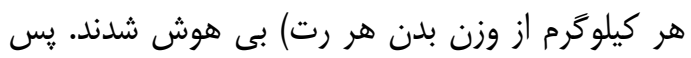

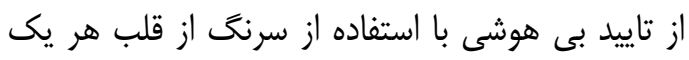
از رت ها نمونه كيرى خون به عمل آمد.

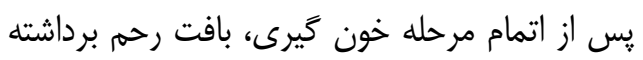

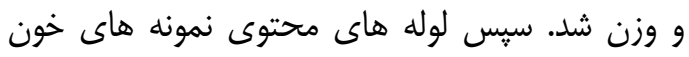
به مدت ها دقيقه با سرعت \& هزار دور در دقيقه

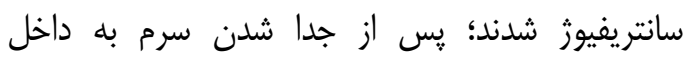

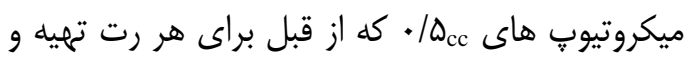

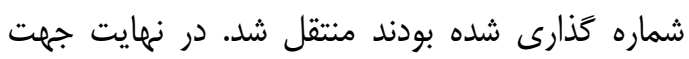

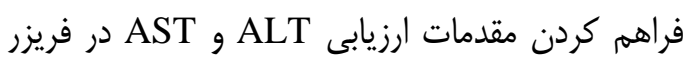

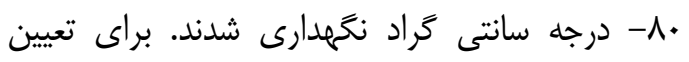
سطح سرمى AST و ALT در اين يزوهش از كيت دراني تشخيص AST و ALT در سرم(يارس آزمون، تهران، ايران) با روش فوتومتريك استفاده شد. 


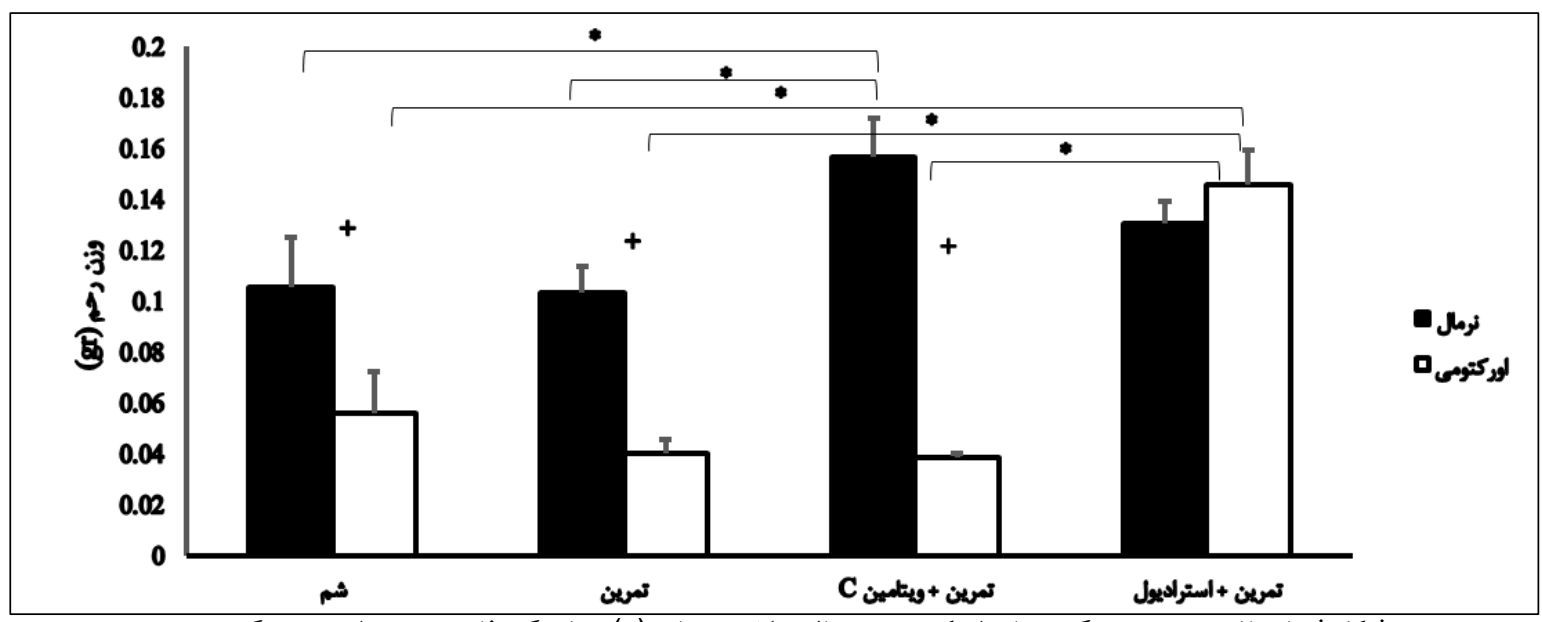

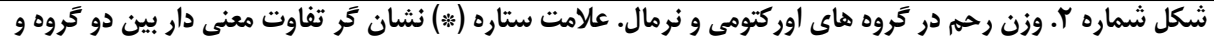

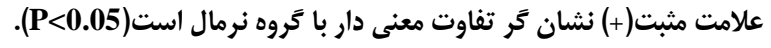

نرمال(P=0.028) و گروه تمرين +ويتامين C اوركتومى نسبت به گروه تمرين+ويتامين C نرمال(P=0.010) به

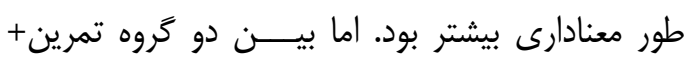

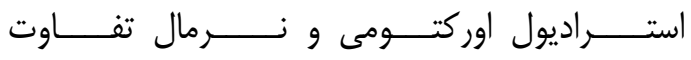

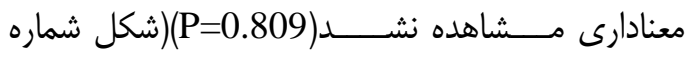

در رابطه با سطح ALT كبد نتايج تحقيق حاضر

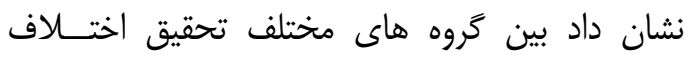
معنى دارى وجود دارد(F=3.34, P=0.005). نتايج

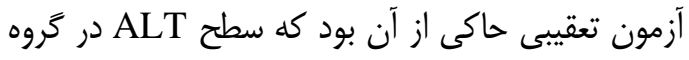

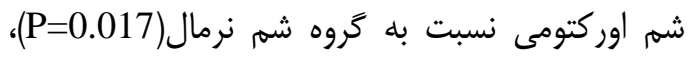

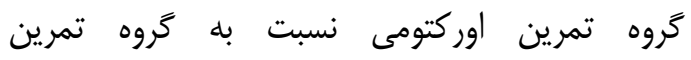

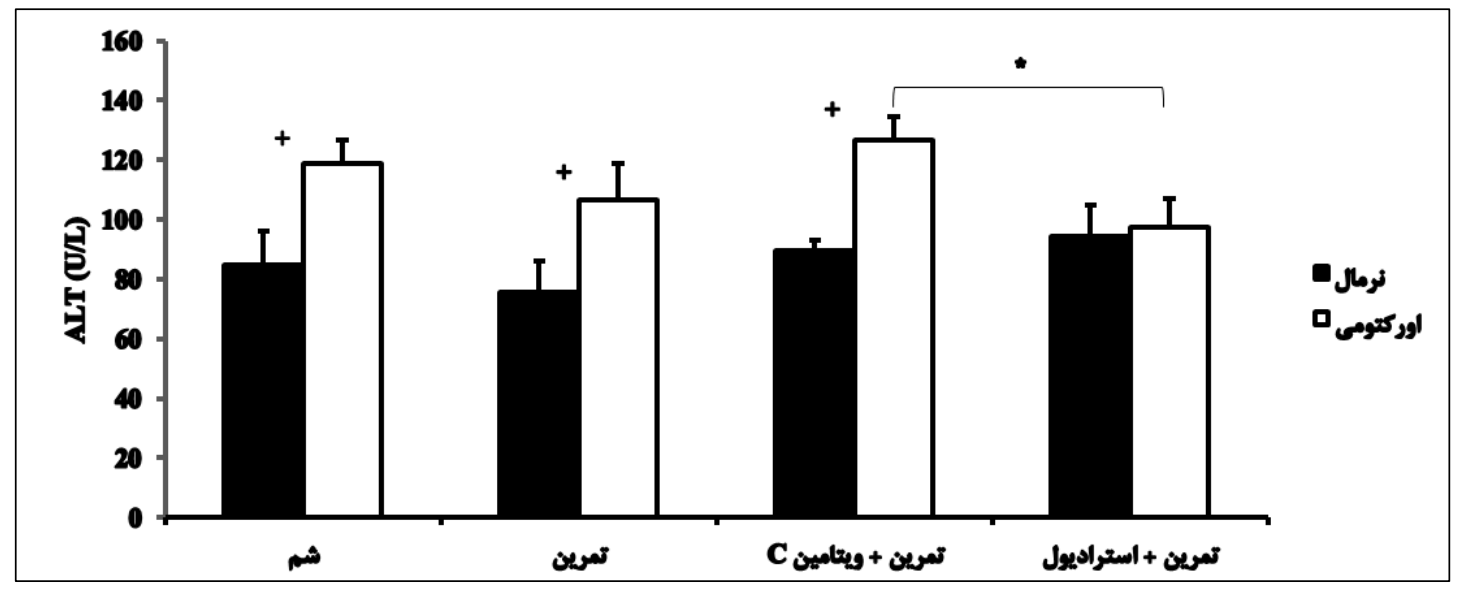

شكل شماره س. سطح ALT كبد در تَروه هاى اوركتومى و نرمال. علامت ستاره(:) نشان تَر تفاوت معنى دار بين دو تَروه

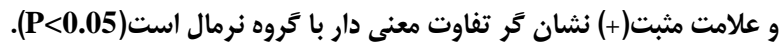

نســـبت به خـــــروه تمرين نرمال(P=0.001) و گروه

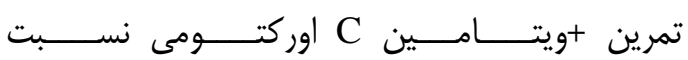
به گروه تمرين +ويتامين C نرمال(P=0.000) به طورين

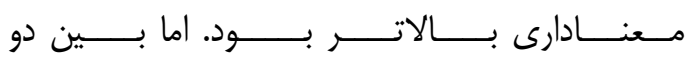

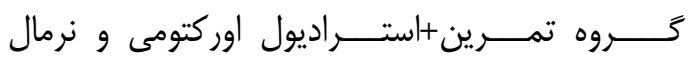
تفاوت معنادارى مشاهده نشد(P=0.154)(شكل شماره
هم هنين نتايج نشان داد كه بين گروه هاى مختلف تحقيق اختلاف معنادارى در سطح AST بافت كبد وجود دارد(F=6.28, P=0.000). نتايج آزمون تعقيبى نشان داد كه سطح AST در گروه هاى اوركتومى بيشتر از گروه هاى نرمال بوده است. در اين رابطه سطح AST در گروه شم اوركتومى نسبت به به يه

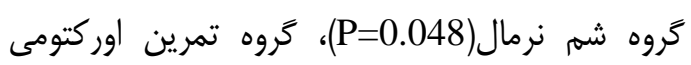




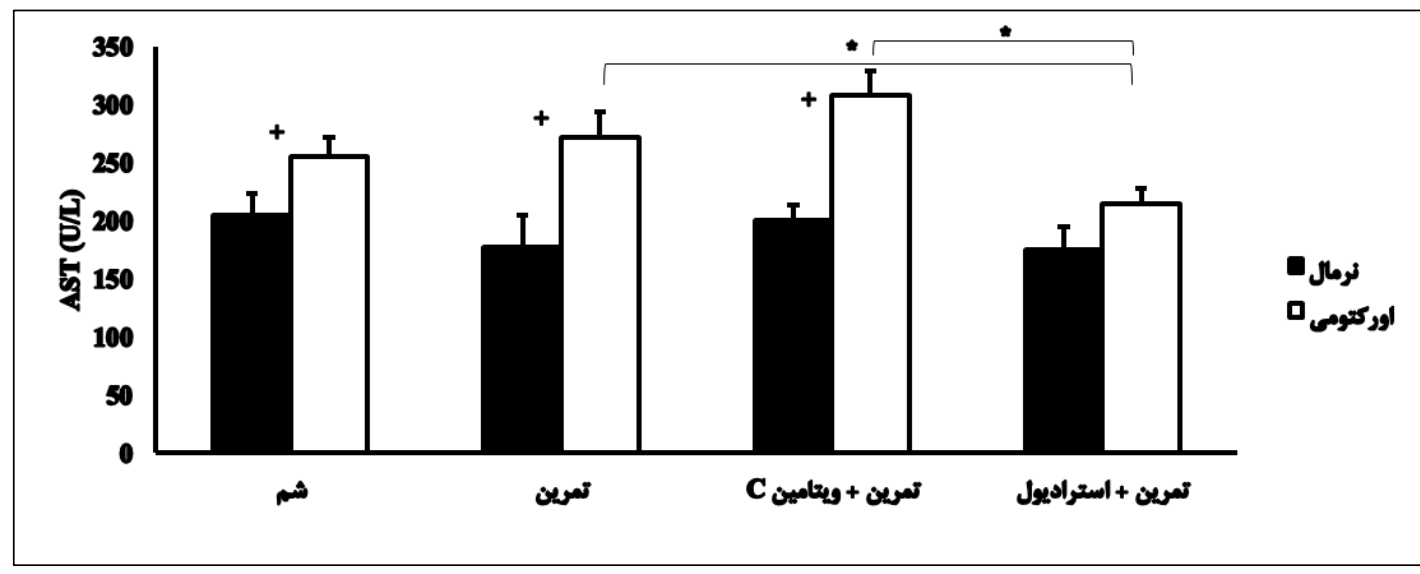

شكل شماره ع. مقايسه سطح AST كبد در تروه هاى اور كتومى و نرمال. علامت ستاره(") نشان تر تفاوت معنى دار بين

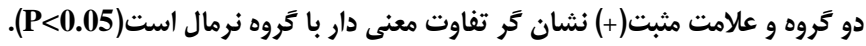

بينابينى در رحم ايجاد مى شود كه ناشى از افزايش

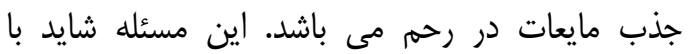

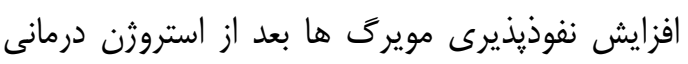
ارتباط داشته باشد؛ كه حداقل بخشى از آن توسط عوامل رشد مثل فاكتور رشد اندوتليال عروقى، فاكتور رشد شبه انسولين و فاكتور رشد ايىدرمال واسطه كرى مى شود(ع). باه هر حال نتايج تحقيق حاضر نيز نشان داد كه اوركتومى منجر به كاهش و آتروفى وزن رحم مى شود و مصرف استراديول از آن ييشخيرى مى كنئد.

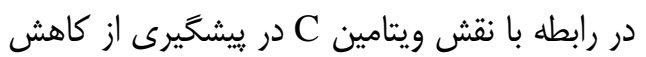

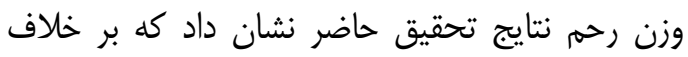

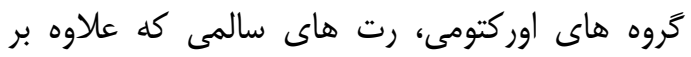
تمرين ويتامين C نيز دريافت كرده بودند، نسبت به

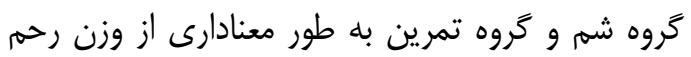

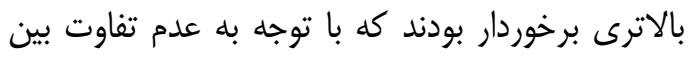

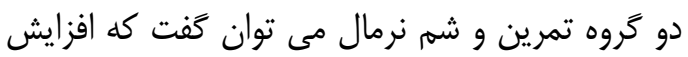

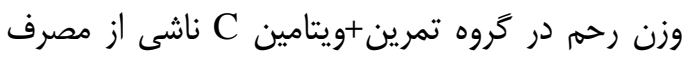

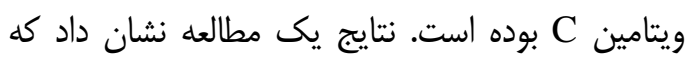

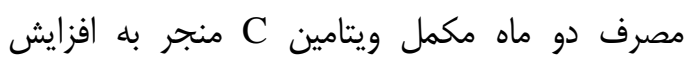

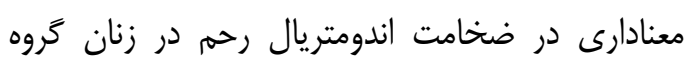

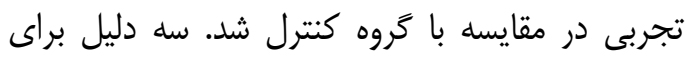

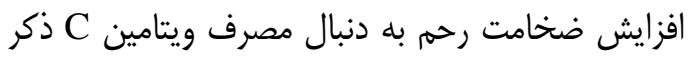
شده است. اول اين كه ويتامين C ممكن است اثر غير

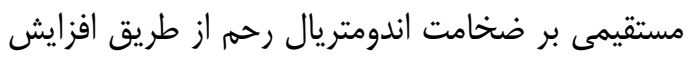
هورمون هاى تخمدانى يروزسترون و استروزن داشته

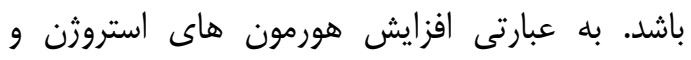

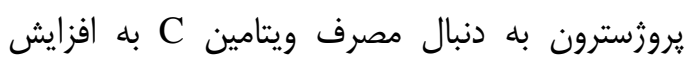

بحث و نتيجه كيرى

نتايج تحقيق حاضر نشان داد كه در گروه هاى

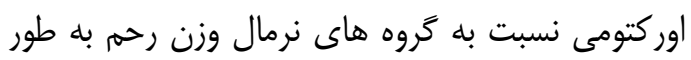

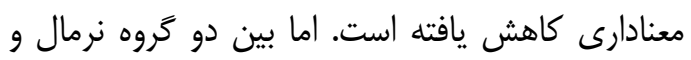

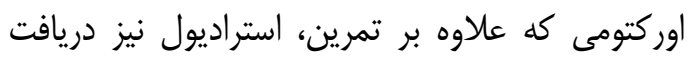

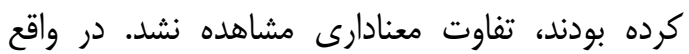

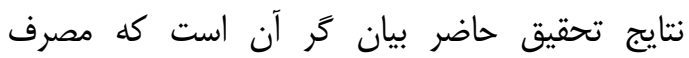
استراديول از كاهش وزن رحم جلوكيرى مى كى كند كه بان

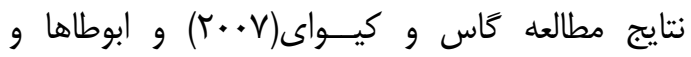

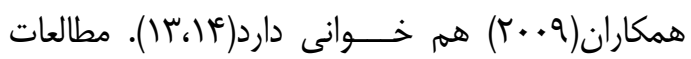
كاهش وزن رحم در رت هاى اوركتومى شده را بـ به عنوان مدرى و دليلى بر موفقيت كامل اوركتومى دونى ذكر

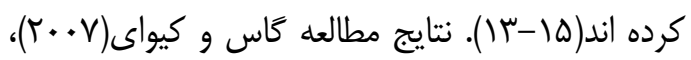

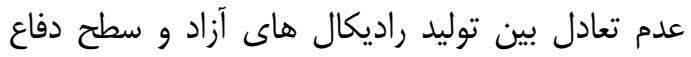

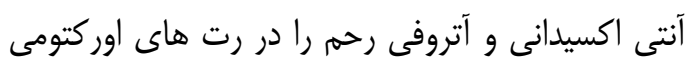

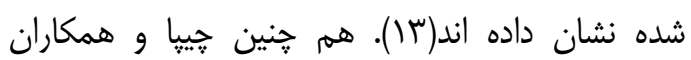

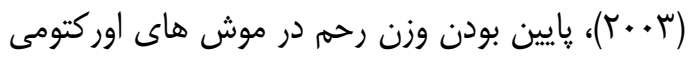

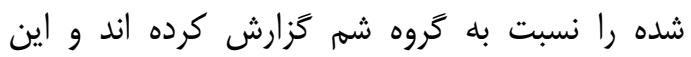

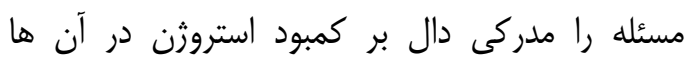
دانسته اند(ها). محققين ديخر، نيز با اشاره به اين كه

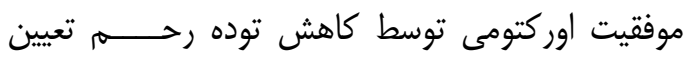

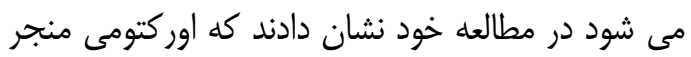
به كاهش قابل توجه(VD درصد) وزن رحم در رت هاى

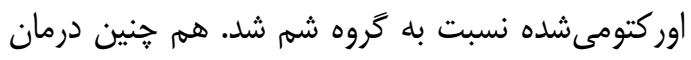
طولانى مدت رت هاى اوركتومى شده با استراديول

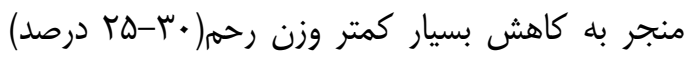
شد(أl). در حقيقت به دنبال استروثن درمانى نوعى ادم 
اوركتومى هم جنين باعث رسوب كلازن بينابينى

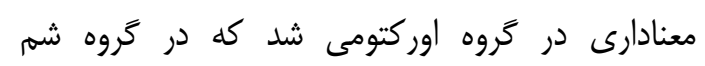

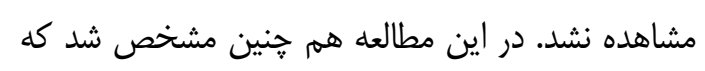

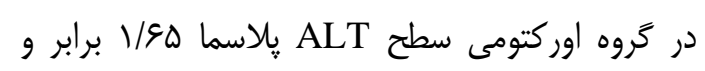

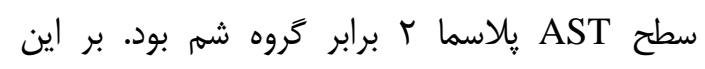

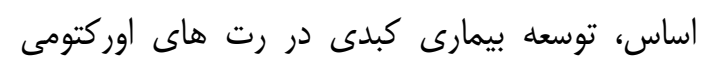

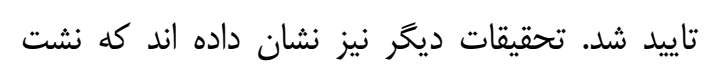
AST ALT و از غشا هياتوسيت ها يكى رويداد ثانويه

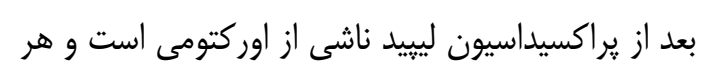

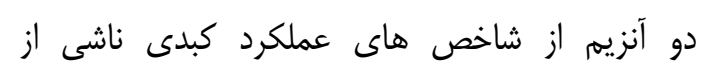

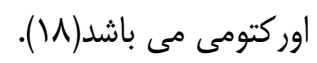
در رابطه با نقش حياتى استرس اكسيداتيو در

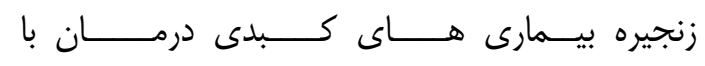

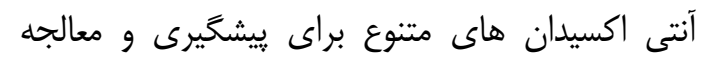

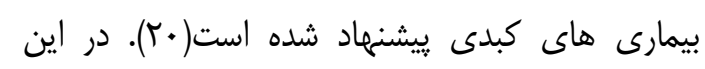

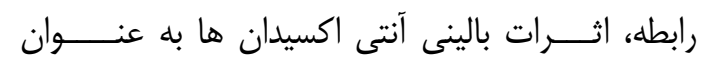

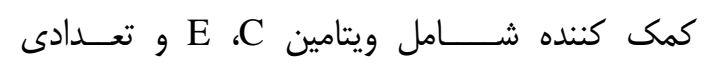

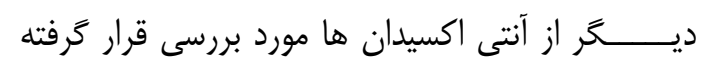

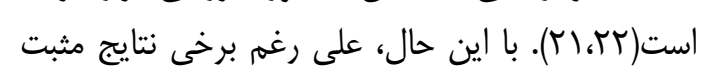

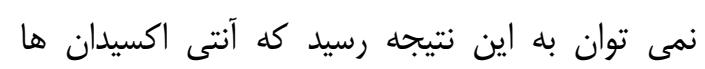
عوامل درمانى مفيدى براى بيمارى هاى كبلى كبدى هستند

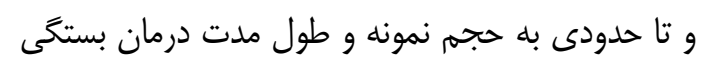

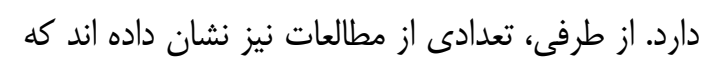

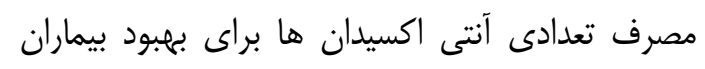

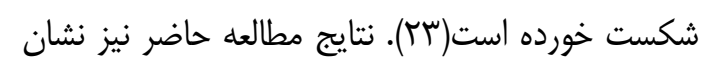
داد كه مصرف ويتامين C از افزايش سطح آنزيم هاى AST و ALT

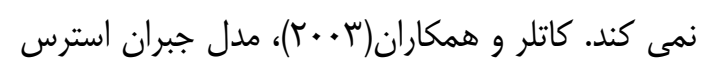

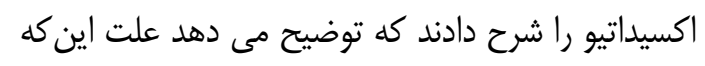

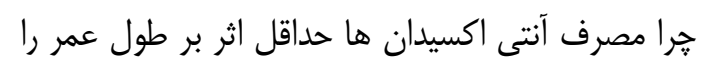

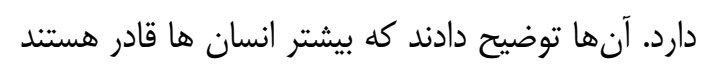

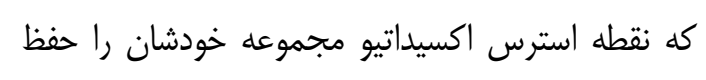

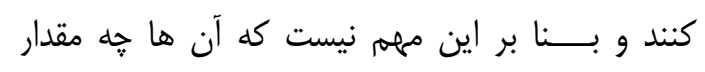
مكمل هاى آنتى اكسيدان در رزيم غذايى خودشان مصرف مى كنند و منجر به كاهش بيشترى در استرس أنسي

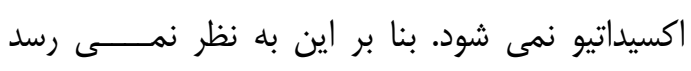
مكمل هاى آنتى اكسيدان استرس اكسيداتيو را به طور

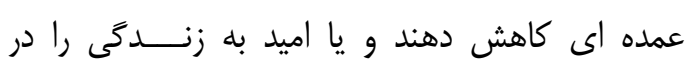

ضخامت اندومتريال رحم كمك مى كند. دوم اين كه بر

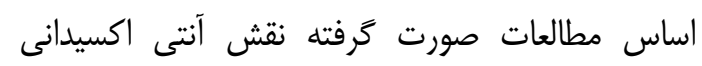

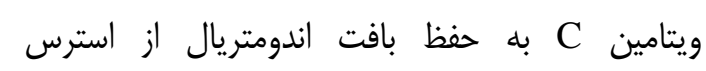

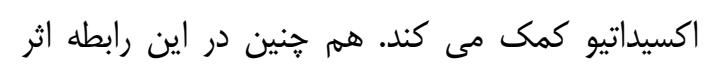
مكمل ويتامين C بر ضخامت اندومتريال رحم ممكن

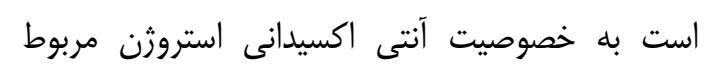

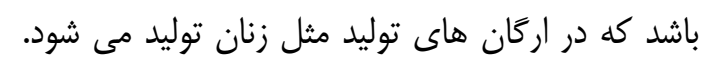

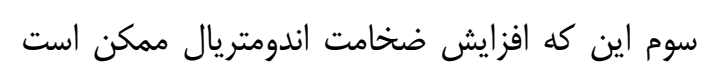
به نقش ويتامين C به عنوان يك أنه كوفاكتور در سنتز كلازن در ماتريكس خارج سلولى در مرحله لوتئال

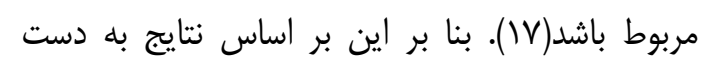

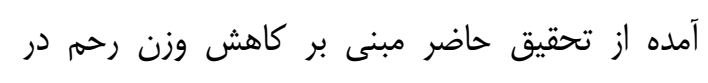

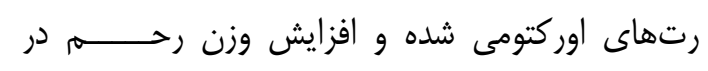
رت هاى نرمالى كه ويتامين C دريافت كرده بون بودنده مىتوان كفت كه مصرف ويتامين C در دوران يائسكى نكى

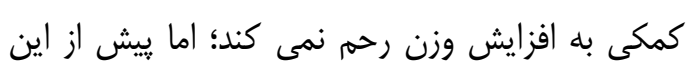

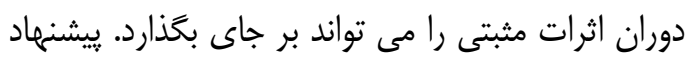
مى شود كه در مطالعات بعد تاثير مصرف مكمل دئل

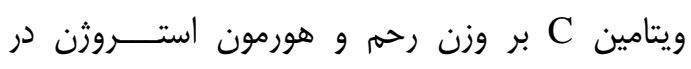

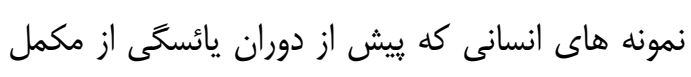

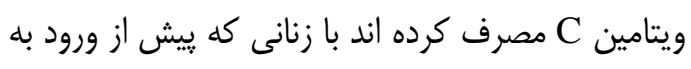

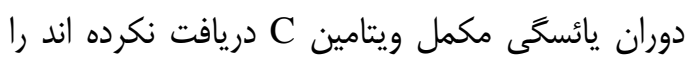
هِ از دوران يائسگى مورد مقايسه و مطالعه قرار گيرد.

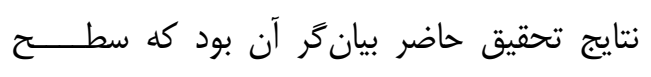
آنزيم هاى ALT و AST در رت هاى اوركتومى شده نسبت به رت هاى نرمال به طور معنادارى بيشتر بود كه با نتايج ديگر مطالعات هم خوانى دارد(9، (19).

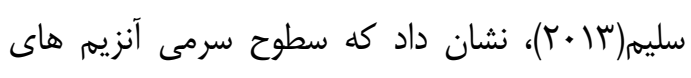

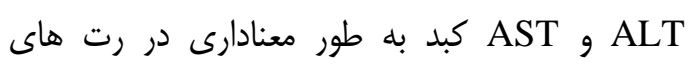

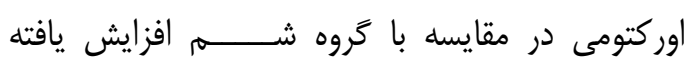

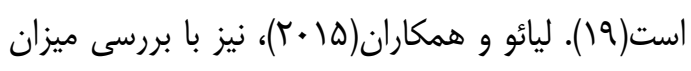

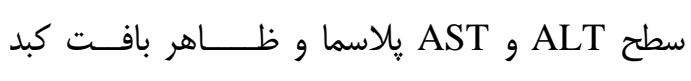
رت هاى اوركتومى شده در مقايسه با گروه شم نشان

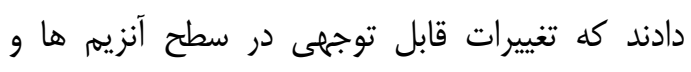

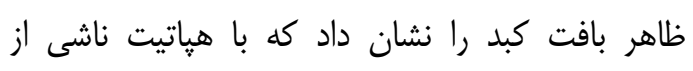
اوركتومى ساز

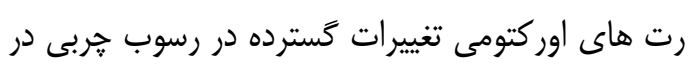
بخش هاى كبد در مقايسه با كروه شم دم داشتند. 
فعاليتهاى ورزشى كَناكون و يك اركان مهرم در حمله به ROS مى باشد(ع)). در دهله هاى اخير، برخى

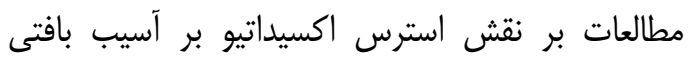
ناشى از ورزش و نقش عوامل آنتى اكسيدانى در آغاز فرآيندهاى سازكارى متمركز شده اند. شواهد موجود

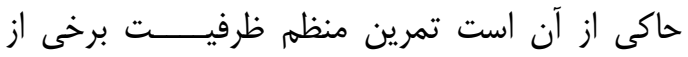
بافت ها براى رهايش ROS را كاهش داده و منجر به

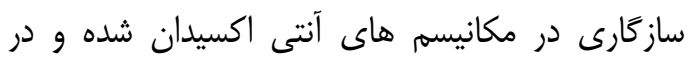

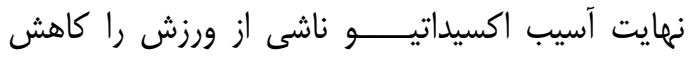

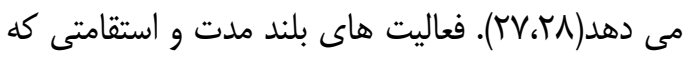

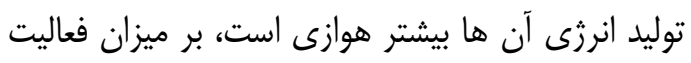

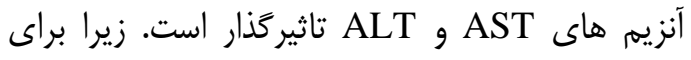

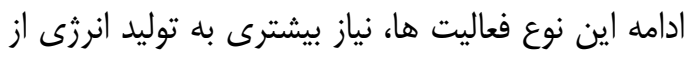

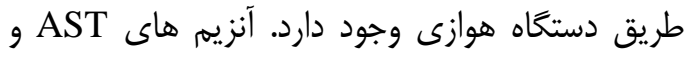

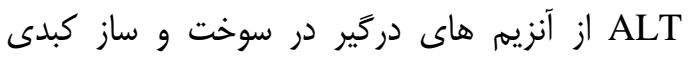

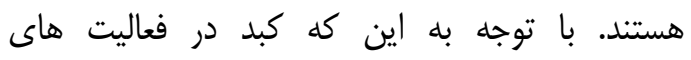
استقامتى بيشتر از ديخر فعاليت ها نقش دارد؛ دان در نتيجه

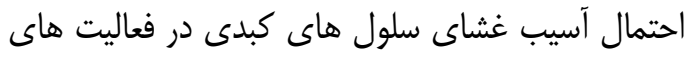

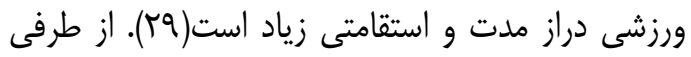

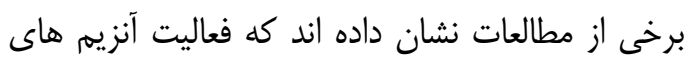

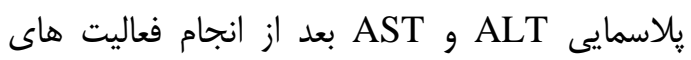

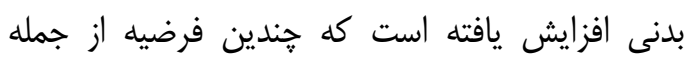

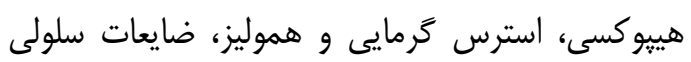

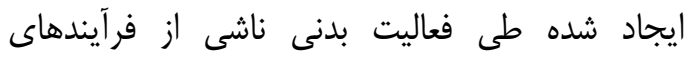

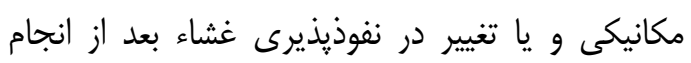

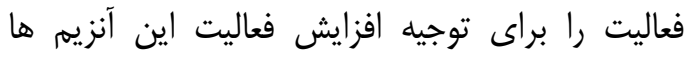

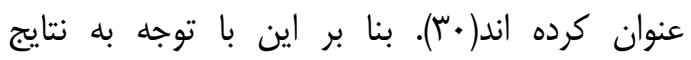

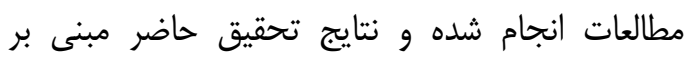

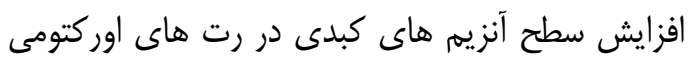

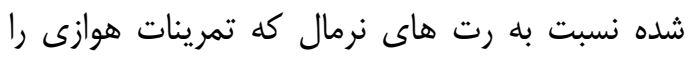

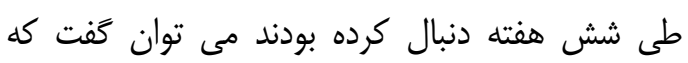

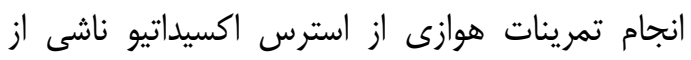

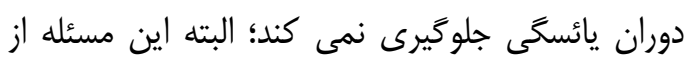

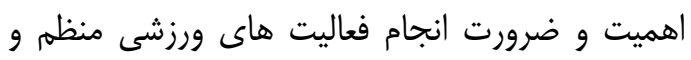

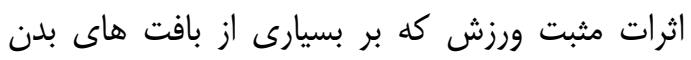

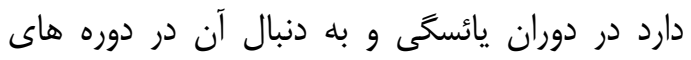

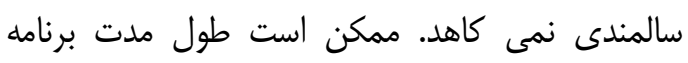
انجام شده در تحقيق حاضر به اندازه اى نبوده كه
انسان ها افزايش دهند(זَ). بنا بر اين به نظر مى رسد كه مصرف ويتامين C تاثيرى بر كاهش استرس اكسيداتيو ناشى از دوران يائسكى ندارد. بر اين اساس كاس كانس ييشنهاد مى شود كه تحقيقات بيشترى در اين زمينه

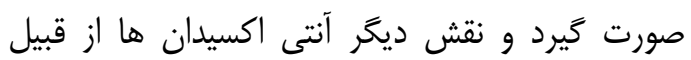
ويتامين E نيز مورد مطالعه قرار كَيرد. در مطالعه حاضر مشخص شد كه سطح ALT و كبد در رت هاى اوركتومى شده كه در كنار

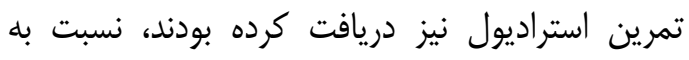

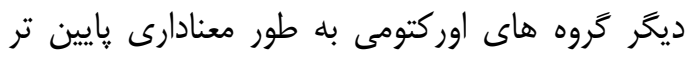

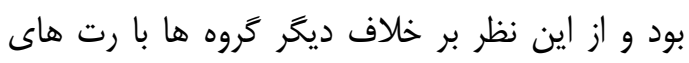

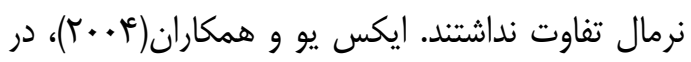

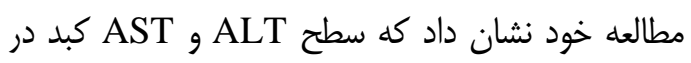
رت هاى اوركتومى شده به دنبال مصرف استراديول

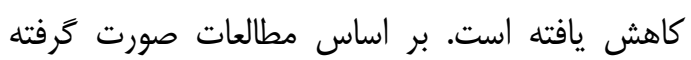

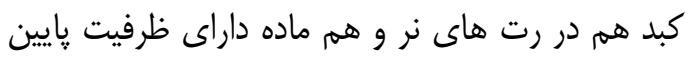

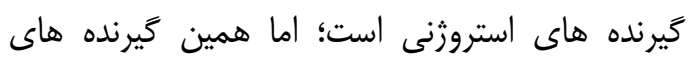

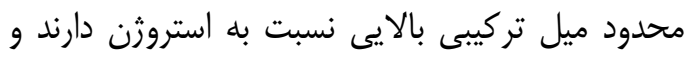

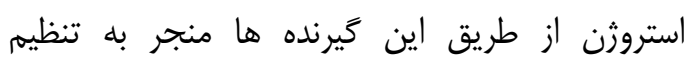

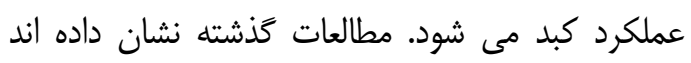

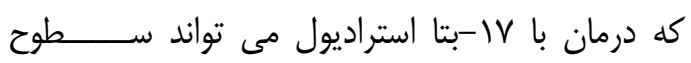

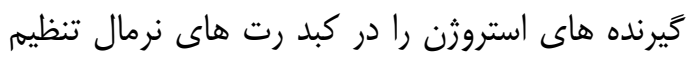

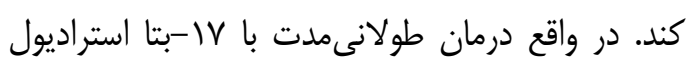
سطح گيرنده هاى استروزن در سلول هاى اندوتليال سينوسى كبدى و سلول هاى كويفر در رت هاى هاى اوركتومى شده را افزايش مى دهد. اين مشاهدات تاكيد

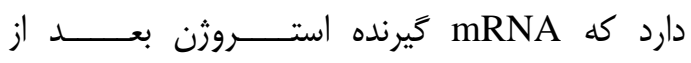

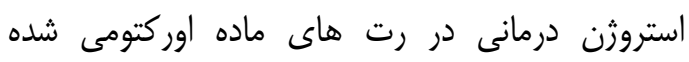

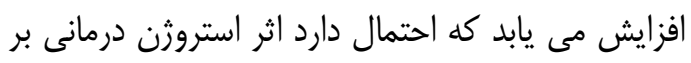

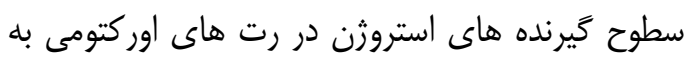
صورت غير مستقيم از طريق غده هييوفيز يا توسط أنران

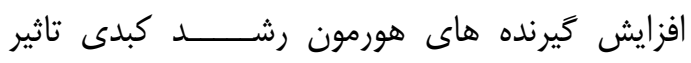

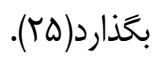
نتايج تحقيق حاضر نشان داد كه سطح آنزيم هاى

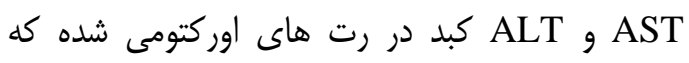

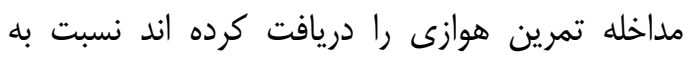
كروه هاى نرمال متناظر خود افزايش معنادارى ئرئ يافته

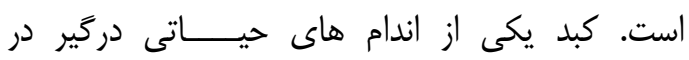




$$
\begin{aligned}
& \text { را به دنبال دارند. اما تمرين هوازى همراه با مصرف } \\
& \text { ويتامين C از افزايش سطوح اين دو آنزيم در رت هاى } \\
& \text { اور كتومى شده جلوكيرى نمى كنند. }
\end{aligned}
$$

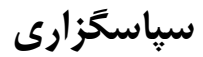

$$
\begin{aligned}
& \text { مطالعه حاضر بركرفته از رساله دكترى بيوشيمى و } \\
& \text { متابوليسم ورزشى است كه با حمايت دانشعاه اصفهان }
\end{aligned}
$$

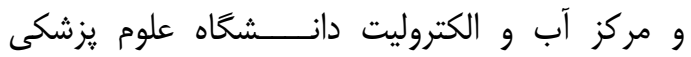

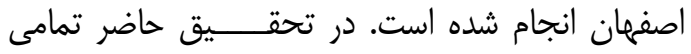

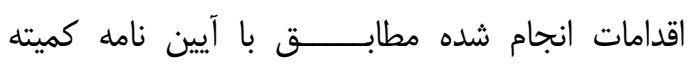

$$
\begin{aligned}
& \text { اخلاق يزوهش بر حيوانات آزمايشحاهى صورت كرفته }
\end{aligned}
$$

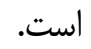

\section{References}

1.Michailidis Y, Karagounis LG, Terzis G, Jamurtas AZ, Spengos K, Tsoukas D, et al. Thiol-based antioxidant supplementation alters human skeletal muscle signaling and attenuates its inflammatory response and recovery after intense eccentric exercise. Am J Clin Nut 2013;98:233-45.doi: 10.3945/ajen.112.049163.

2. Maroti T, Sobocanec S, Safranko Z, Saric A, Kusic B, Balog T. Sensitivity to oxidative stress sex matters. Med Sci 2010;35:59-68.

3. Doshi SB, Agarwal A. The role of oxidative stress in menopause. J Mid Health2013;4:140. doi: 10.4103/09767800.118990 .

4. Fukui A, Kawabe N, Hashimoto S, Murao M, Nakano T, Shimazaki H, et al. Vitamin $\mathrm{E}$ reduces liver stiffness in nonalcoholic fatty liver disease. World $\mathrm{J}$ Hepatol2015;7:2749.

doi: 10.4254/wjh.v7.i27.2749.

5. Ji L, Cabrera M, Steinhafel N, Vina J. Acute exercise activates nuclear factor NF$\kappa \mathrm{B}$ signaling pathway in rat skeletal muscle. FASEB J 2004;18:1499-506. doi:10.1096/fj.04-1846com.

6. Macedo UBdO, Martins RR, Neto FP, Oliveira YMdC, Medeiros AdC, Brandao J, et al. Oophorectomy hinders antioxidant adaptation promoted by swimming in wistar Rats. Appl Physiol Nut Metab 2013;38:148-53. doi: 10.1139/apnm-20120121.

7. Rodrigues MFC, Stotzer US, Domingos MM, Deminice R, Shiguemoto GE, Tomaz LM, et al. Effects of ovariectomy and

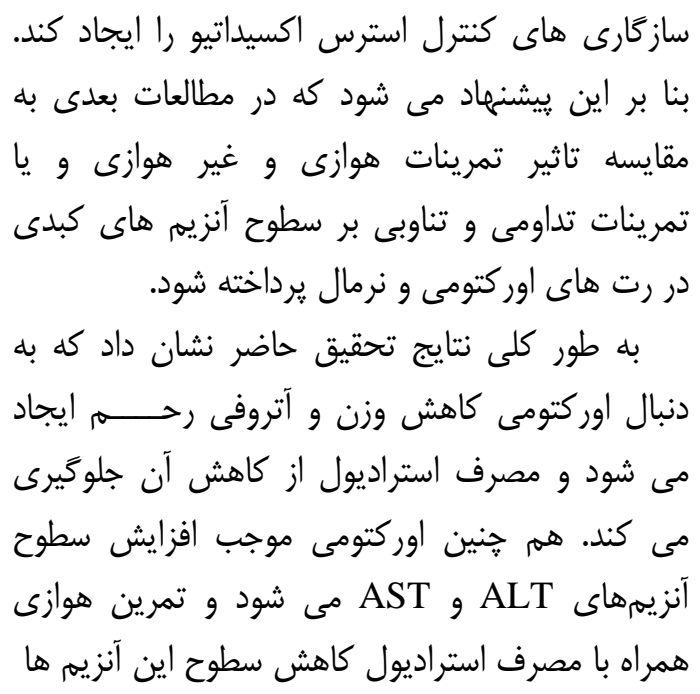

resistance training on oxidative stress markers in the rat liver. Clinics. 2013; 68(9):1247-54.

doi: 10.6061/clinics/2013(09)12.

8. Kankofer M, Radzki R, Bienko M, Albera E. Anti oxidative status of Rat liver after ovariectomy. Trans Emerg Dis 2007;54:225-9. doi:1439-

0442.2007.00916.x.

9. Videlal LA, Rodrigo R, Orellana M, Fernandez V, Tapia G, Quinones L, et al. Oxidative stress related parameters in the liver of non alcoholic fatty liver disease patients. Clin Sci2004; 106:261-8. doi:10.1042/CS20030285.

10. Shephard RJ, Johnson N. Effects of physical activity upon the liver. European $\mathbf{J}$ Appl physiol2015;115:146. doi:10.1007/s00421-014-3031-6.

11. Nematbakhsh M, Pezeshki Z, Eshraghijazi F, Ashrafi F, Nasri H, Talebi $\mathrm{A}$, et al. Vitamin $\mathrm{E}$ and vitamin $\mathrm{C}$ or losartan is not nephroprotectant against cisplatin induced nephrotoxicity in presence of estrogen in ovariectomized rat model. Int $\mathrm{J}$

8.doi: 10.1155/2012/284896.

Nephrol2012;2:121-

12. Almeida SA, Claudio ER, Mengal V, Oliveira SG, Merlo E, Podratz PL, et al. Exercise training reduces cardiac dysfunction and remodeling in ovariectomized rats submitted to myocardial infarction. PLos One 2014; 9: 115970. doi: 10.1371/journal. pone.0115970.

13. Goss PE, Qi S, Hu H, Cheung AM. The effects of atamestane and toremifene alone and in combination compared with letrozole 
on bone, serum lipids and the uterus in an ovariectomized Rat model. Breast Cancer Res Treat2007;103:293-302. doi:10.1007/ s10549-006-9381-y.

14. Abutaha M, Rius C, Hermenegildo C, Noguera I, Nicolas JM, Issekutz AC, et al. Menopause and ovariectomy cause a low grade of systemic inflammation that may be prevented by chronic treatment with low doses of estrogen or losartan. J Immunol 2009;183:1393-402.

doi:

10.4049/jimmunol.0803157.

15. Chiba $\mathrm{H}$, Uehara $\mathrm{M}$, Wu J, Wang $\mathrm{X}$, Masuyama R, Suzuki K, et al. Hesperidin, a citrus flavonoid, inhibits bone loss and decreases serum and hepatic lipids in ovariectomized mice. J Nut 2003;133:18927. doi:10.1093/jn/133.6.1892.

16. Lindberg MK, Weihua Z, Andersson N, Moverare S, Gao H, Vidal $\mathrm{O}$, et al. Estrogen receptor specificity for the effects of estrogen in ovariectomized Mice. J Endocrinol2002;174:167-78. doi: 00220795/02/0174-167.

17. Sami R. Alkatib, Meissam MH. Alkaabi, Karim A. Aljashamy. Effects of vitamin $\mathrm{C}$ on the endometrial thickness and ovarian hormones of progesterone and estrogen in married and unmarried women. Am J Res Commun 2013; 1: 24-31.

18. Liao CC, Chiu YS, Chiu WC, Tung YT, Chuang $\mathrm{HL}, \mathrm{Wu} \mathrm{JH}$, et al. Proteomics analysis to identify and characterize the molecular signatures of hepatic steatosis in ovariectomized Rats as a model of postmenopausal status. Nutrients2015;7:8752-66. doi: $10.3390 / \mathrm{n} \mathrm{u} 7105434$.

19. Salim S. Al-Rejaie. Thymoquinone Treatment Alleviate Ovariectomy-Induced Hepatic Oxidative Damage in Rats. J App Pharm Sci2013; 3: 126-31. doi: 10.7324/JAPS.2013.3621.

20. Li AN, Li S, Zhang YJ, Xu XR, Chen $\mathrm{YM}, \mathrm{Li} \mathrm{HB}$. Resources and biological activities of natural polyphenols. Nutrients2014;6:6020-47. doi: $10.3390 /$ nu6126020.

21.Esrefoglu M. Oxidative stress and benefits of antioxidant agents in acute and chronic hepatitis. Hepat Month 2012;12:160-7. doi: 10.5812/hepatmon.837.
22. Emerit I, Huang CY, Serejo F, Filipe P, Fernandes A, Costa A, et al. Oxidative stress in chronic hepatitis $\mathrm{C}$ a preliminary study on the protective effects of antioxidant flavonoids. Hepat Gastroenterol 2005; 52:530-6. doi: 0000-0001-6917$527 \mathrm{X}$.

23. Zhao J, Fan YC, Zhang F, Yang Y, Zhao ZH, Sun FK, et al. Oxidative stress in chronic hepatitis $\mathrm{C}$ patients. Chinese J Exp clin Virol 2013; 27:47-9.

24. Cutler RG. Genetic stability and dysdifferentiationand longevity determinant genes. $3^{\text {th }}$ ed. Sunders Publication. 2003;P. 1146-235.

25. Xu JW, Gong J, Chang XM, Luo JY, Dong L, Jia A, et al. Effects of estradiol on liver estrogen receptor alpha and its mRNA expression in hepatic fibrosis in Rats. World J Gastroenterol 2004;10:250-4. doi: 10.3748/wjg.v10.i2.250.

26.Sanchezvalle V, Chaveztapia NC, Uribe M, Mendezsanchez N. Role of oxidative stress and molecular changes in liver fibrosis: a review. Curr Med Chem2012; 19:4850-60. doi: 10.2174/0929867128033 41520.

27. Wassmann S, Wassmann K, Nickenig G. Modulation of oxidant and antioxidant enzyme expression and function in vascular cells. Hypertension 2004;44:381-6. doi:10.1161/01.HYP.0000142232.29764.a7 28. Leeuwenburgh C, Heinecke JW. Oxidative stress and antioxidants in exercise. Curr Med Chem 2001;8:829-38. doi: 10.2174/0929867013372896.

29. Bashiri J, Gaeini A, Nikbakht H, Hadi $\mathrm{H}$, Bashiri M. [Effect of concurrent creatine monohydrate ingestion and resistance training on hepatic enzymes activity levels in non athlete Males]. IJEM2010;12:42-7. (Persian)

30.Podhorskaokolow M, Dziegiel P, Cialowicz E, Saczko J, Kulbacka J, Gomulkiewicz A, et al. Effects of adaptive exercise on apoptosis in cells of Rat renal tubuli. European J Appl Physiol 2007; 99:217-26. doi: 10.1007/s00421-006-03351. 


\title{
Comparison of the Effects of Aerobic Training with Vitamin C and Estradiol on Markers of the Liver among Ovariectomized and Normal Rats
}

\author{
Abbasi $M^{1 *}$, Bambaeichi $E^{2}$
}

(Received: April 4, 2018

Accepted: October 15, 2018)

\begin{abstract}
Introduction: Postmenopausal estrogen deficiency, disturbance of the antioxidant defense system, and free radical production lead to oxidative stress. This results in metabolic disturbances affecting the liver. Therefore, it is important to properly evaluate the benefits of antioxidant administration and exercise on oxidative stress in the liver. The main purpose of this study was to compare the effects of aerobic training with vitamin $\mathrm{C}$ and estradiol on oxidative stress in the liver among ovariectomized and normal rats.
\end{abstract}

Materials \& Methods: In total, sixty-four female rats were divided into two groups of normal $(n=32)$ and ovariectomized $(n=32)$. Each group was subdivided randomly into four subgroups consisting of sham, training, training+vitamin $\mathrm{C}$, and training+estradiol. The experimental protocol was five 60-min running sessions for six weeks on a treadmill with average intensity and 55\% Vo2max. Moreover, the rats were subjected to the injection of $250 \mathrm{mg}$ and $0.25 \mathrm{mg} / \mathrm{kg}$ vitamin $\mathrm{C}$ and estradiol, respectively. Liver oxidative damage was determined by the serum levels of alanine aminotransferase (ALT) and aspartate aminotransferase (AST).

Findings: According to the results, ovariectomy resulted in vaginal atrophy. Moreover, it led to a significant increase in AST and ALT levels. In addition, the administration of estradiol decreased the serum level of these enzymes $(\mathrm{P}<0.05)$. However, aerobic training and vitamin $\mathrm{C}$ had no effect on the prevention of the increased levels of these enzymes in ovariectomized rats $(\mathrm{P}<0.05)$.

Discussion \& Conclusions: In conclusion, the obtained results revealed that average intensity training had no effect on the prevention of increased levels of oxidative stress in ovariectomized rats. However, exercise training in combination with estradiol and vitamin $\mathrm{C}$ improved oxidative stress conditions in ovariectomized rats.

Keywords: Aerobic training, Estradiol, Menopause, Ovariectomy, Oxidative stress, Vitamin C

1. Dept of Exercise Physiology, Islamic Azad University, Ilam Branch, Ilam, Iran

2. Dept of Exercise Physiology, Faculty of Sports Sciences, University of Isfahan, Isfahan, Iran

* Corresponding author Email: Abbasimaryam60@yahoo.com

Scientific Journal of Ilam University of Medical Sciences 